\title{
Daytime Variation in Serum Progesterone During the Mid-Luteal Phase in Women Undergoing In Vitro Fertilization Treatment
}

\author{
Lise Haaber Thomsen ${ }^{1,2 *}$, Ulrik Schiøler Kesmodel ${ }^{3,4}$, Claus Yding Andersen $^{5}$ \\ and Peter Humaidan ${ }^{1,2}$
}

\begin{abstract}
${ }^{1}$ The Fertility Clinic, Skive Regional Hospital, Skive, Denmark, ${ }^{2}$ Department of Clinical Medicine, Aarhus University, Aarhus, Denmark, ${ }^{3}$ The Fertility Clinic, Herlev Hospital, Herlev, Denmark, ${ }^{4}$ Department of Clinical Medicine, University of Copenhagen, Copenhagen, Denmark, ${ }^{5}$ Laboratory of Reproductive Biology, The Juliane Marie Centre for Women, Children and Reproduction, University Hospital of Copenhagen, University of Copenhagen, Copenhagen, Denmark
\end{abstract}

OPEN ACCESS

Edited by:

Sandro C. Esteves, Androfert, Andrology and Human Reproduction Clinic, Brazil

Reviewed by: Evangelos G. Papanikolaou, Aristotle University of

Thessaloniki, Greece John Lui Yovich,

Pivet Medical Center, Australia

*Correspondence: Lise Haaber Thomsen lise.thomsen@midt.rm.dk

Specialty section: This article was submitted to Reproduction, a section of the journal Frontiers in Endocrinology

Received: 17 December 2017 Accepted: 26 February 2018 Published: 19 March 2018

Citation:

Thomsen LH, Kesmodel US, Andersen CY and Humaidan P (2018)

Daytime Variation in Serum Progesterone During the Mid-Luteal Phase in Women Undergoing In Vitro Fertilization Treatment.

Front. Endocrinol. 9:92. doi: 10.3389/fendo.2018.00092
Objective: To investigate whether mid-luteal serum progesterone $\left(\mathrm{P}_{4}\right)$ exhibits significant fluctuations during a 12-h daytime period in women undergoing in vitro fertilization (IVF) and to explore whether the extent of these fluctuations could impact the interpretation of luteal progesterone levels in a clinical setting.

Design: Explorative pilot study.

Setting: Public hospital-based fertility unit.

Patients: Ten women undergoing IVF treatment.

Intervention: Seven days after oocyte pick-up, patients underwent frequent repeated blood sampling (every 60 min for $12 \mathrm{~h}$ and during two of these hours, every $15 \mathrm{~min}$ ). Serum samples were analyzed for progesterone, estradiol, and luteinizing hormone (LH).

Main outcome measures: Daytime fluctuations in s-progesterone and s-estradiol.

Results: There was a significant positive correlation between median $\mathrm{P}_{4}$ levels and the magnitude of $\mathrm{P}_{4}$ variations - women with median $\mathrm{P}_{4}<60 \mathrm{nmol} / \mathrm{l}$ had clinically stable $\mathrm{P}_{4}$ levels throughout the day, while patients with median $\mathrm{P}_{4}>250 \mathrm{nmol} / \mathrm{l}$ exhibited periodic $\mathrm{P}_{4}$ peaks of several hundred nanomoles per liter. These endogenous $\mathrm{P}_{4}$ fluctuations were observed irrespective of the type of stimulation protocol or mode of triggering of final oocyte maturation and despite the fact that LH was under the detection limit at the time of measurement. Simultaneously, large fluctuations were seen in s-estradiol.

Conclusion: Monitoring of early to mid-luteal $\mathrm{P}_{4}$ levels in IVF cycles may be valuable in the planning of individualized luteal phase support in the attempt to increase reproductive outcomes. The prerequisite for luteal phase monitoring is, however, that the validity of a single measured $\mathrm{P}_{4}$ value is reliable. We show for the first time, that a single $\mathrm{P}_{4}$ measurement in the low progesterone patient quite accurately reflects the corpus luteum function and that the measurement can be used to detect IVF patients with a need of additional exogenous luteal $\mathrm{P}_{4}$ administration.

Keywords: serum progesterone, in vitro fertilization, serum estradiol, luteal phase, daytime variation 


\section{INTRODUCTION}

The human corpus luteum (CL) is a transient ovarian endocrine gland, which is active during the luteal phase of the menstrual cycle and in early pregnancy until gestational week 8 . The CL produces significant amounts of progesterone $\left(\mathrm{P}_{4}\right)$, estradiol $\left(\mathrm{E}_{2}\right)$, and androgens as well as growth factors and nonsteroidal hormones. The overall maintenance of CL function is critically dependent upon regular stimulation of pituitary luteinizing hormone (LH) or human chorionic gonadotropin (hCG) to sustain the steroidogenesis from the luteinized granulosa and theca cells (1). A sufficient $\mathrm{P}_{4}$ production from the $\mathrm{CL}$ is an absolute necessity for the decidualization of the endometrium preceding implantation and the establishment of early pregnancy. Progesterone secretion from the $\mathrm{CL}$ is maximal during the mid-luteal phase inducing a serum $\mathrm{P}_{4}$ level of approximately $40-60 \mathrm{nmol} / \mathrm{l}$ in the natural cycle $(2,3)$.

During ovarian stimulation for in vitro fertilization (IVF) supra-physiological levels of $\mathrm{E}_{2}$ are obtained during the late follicular phase as a result of the multifollicular growth. This hyperestrogenic state must be counterbalanced in the luteal phase by an increased $\mathrm{P}_{4}$ load to achieve a receptive endometrium in time for embryo transfer. Previously, Humaidan and co-workers showed that the use of GnRH agonist trigger in IVF cycles followed by a standard vaginal luteal phase support resulted in mid-luteal $\mathrm{P}_{4}$ levels comparable to levels seen in the natural cycle $(39 \mathrm{nmol} / \mathrm{l})$ (4). However, in contrast to what was expected, this $\mathrm{P}_{4}$ level was too low to secure successful implantation and pregnancy, resulting in an ongoing IVF pregnancy rate of only $6 \%$. Thus, emphasizing the fact that the $\mathrm{P}_{4}$ requirement during the luteal phase of the stimulated cycle is greater than that of the natural cycle. When the luteal phase support was modified by adding a bolus of 1,500 IU hCG on the day of oocyte retrieval, the mid-luteal $\mathrm{P}_{4}$ level of the GnRHa triggered cycle increased to $74 \mathrm{nmol} / \mathrm{l}$ resulting in a delivery rate of $24 \%$ per transfer (5). It seems that a midluteal serum $\mathrm{P}_{4}$ threshold of approximately $80-100 \mathrm{nmol} / \mathrm{l}$ exists after IVF treatment followed by fresh embryo transfer, and that this threshold must be surpassed in order to secure a successful reproductive outcome (6). The traditional luteal phase support in artificial IVF cycles with administration of vaginal micronized $\mathrm{P}_{4}$ induces a luteal serum $\mathrm{P}_{4}$ level of approximately $40 \mathrm{nmol} / \mathrm{l}(7-9)$. Thus, a substantial additional endogenous $\mathrm{P}_{4}$ production by the CL is mandatory to surpass the $\mathrm{P}_{4}$ threshold to subsequently optimize the chance of pregnancy following IVF treatment. Traditionally, clinicians do not monitor the luteal phase $\mathrm{P}_{4}$ levels in the firm belief that the luteal phase support will cover the $\mathrm{P}_{4}$ need of the cycle. However, we have previously seen that more than $25 \%$ of IVF patients in both the hCG and GnRHa triggered group have a mid-luteal serum $\mathrm{P}_{4}$ below $60 \mathrm{nmol} / \mathrm{l}$ despite luteal phase support and the fact that they had more than 14 follicles on the day of aspiration (10). Furthermore, data from non-human species $(11,12)$ and data from human frozen/thawed embryo cycles $(13,14)$ have shown that an optimal luteal $\mathrm{P}_{4}$ range exists and that pregnancy outcome is reduced not only below but also above this optimal $\mathrm{P}_{4}$ level. Whether this is also the case following IVF and fresh embryo transfer, is still to be explored. If this is the case, monitoring of luteal $\mathrm{P}_{4}$ levels may help to improve the reproductive outcome in IVF cycles by allowing an individualization of treatment based on the serum $\mathrm{P}_{4}$ measurements.

However, mid-luteal $\mathrm{P}_{4}$ measurements are complicated by the pulsatile nature of hormone secretion from the CL. Filicori and co-workers (15) showed that plasma $\mathrm{P}_{4}$ concentrations exhibit large and rapid fluctuations during the mid-luteal phase of naturally cycling women. Thus, $\mathrm{P}_{4}$ levels ranged from values as low as $7 \mathrm{nmol} / \mathrm{l}$ to peaks of $128 \mathrm{nmol} / \mathrm{l}$ within minutes during a 24-h study period. In the natural cycle, two distinguishable types of $\mathrm{P}_{4}$ pulses exist during the mid-luteal phase: those preceded by an $\mathrm{LH}$ pulse and others emerging at time of $\mathrm{LH}$ quiescence; the latter being a result of an autonomous steroid secretion by the CL independent of LH activity. During the mid-luteal phase of the stimulated IVF cycle, the pituitary is suppressed by the negative feedback from supra-physiological steroid levels and s-LH is significantly reduced to levels much lower $(0.5-0.7 \mathrm{IU} / \mathrm{l})$ than seen in the mid-luteal phase of the natural cycle (5-7 IU/l) (16-18). How this diminished LH pulse activity influences the secretory pattern of ovarian steroidogenesis during the mid-luteal phase of an IVF cycle is until now unknown.

The present study was performed to explore whether midluteal serum $\mathrm{P}_{4}$ levels in an IVF cycle exhibit a similar highpulsatile pattern as seen during the natural cycle, knowing that the LH pulse activity is distinctly reduced. From a clinical point of view, we wanted to investigate whether a single morning $\mathrm{P}_{4}$ measurement provided a reliable index of mid-luteal CL function following IVF treatment.

\section{MATERIALS AND METHODS}

\section{Study Population}

Ten female patients undergoing IVF/ICSI at the Fertility Clinic in Skive, Denmark, from December 2014 to December 2015 volunteered to participate in the study. Clinical information regarding age, body mass index (BMI), smoking habits, biochemical reproductive profile, cause of infertility, prior IVF attempts, course of stimulation, and laboratory results were recorded. Baseline characteristics of participants are provided in Table 1. Written informed consent was obtained from all patients prior to study participation. Participants were chosen so as to represent both the long GnRH agonist cycle as well the GnRH antagonist cycle and different types of triggering for final oocyte maturation (hCG or GnRH agonist).

\section{Protocols for Ovarian Stimulation}

Six patients were treated in a long GnRH agonist cycle with pituitary suppression using SC injection of Buserelin $0.8 \mathrm{mg}$ (Suprefact ${ }^{\circledR}$; Sanofi, Denmark) starting in the mid-luteal phase of the preceding cycle. A daily dose of $0.4 \mathrm{mg}$ Buserelin was administered until the day before ovulation triggering. On day 2 of the cycle, a transvaginal ultrasound examination was carried out, and in case of an endometrial thickness $<4 \mathrm{~mm}$, ovarian stimulation started with corifollitropin-alfa (Elonva ${ }^{\circledR}$; MSD, Denmark) in combination with either r-FSH/rLH (Pergoveris ${ }^{\circledR}$; Merck Biopharma, Denmark) or hMG (Menopur ${ }^{\circledR}$, Ferring Pharmaceuticals, Denmark). The gonadotropin dosage was 
TABLE 1 | Description of demographic data, ovarian stimulation, luteal phase support, and progesterone levels in study patients.

\begin{tabular}{|c|c|c|c|c|c|c|c|c|c|c|c|c|c|}
\hline Patient & Age (years) & $\begin{array}{c}\text { Body mass } \\
\text { index }\left(\mathrm{kg} / \mathrm{m}^{2}\right)\end{array}$ & $\begin{array}{c}\text { Basal } \\
\text { FSH (IU/I) }\end{array}$ & $\begin{array}{l}\text { Cause of } \\
\text { infertility }\end{array}$ & Protocol & $\begin{array}{l}\text { Total FSH } \\
\text { sum (IU) }\end{array}$ & $\begin{array}{l}\text { Duration of } \\
\text { FSH stimulation } \\
\text { (days) }\end{array}$ & Ovulation trigger & $\begin{array}{l}\text { Luteal phase } \\
\text { support }\end{array}$ & $\begin{array}{c}\text { No. of } \\
\text { follicles }> \\
14 \mathrm{~mm}\end{array}$ & $\begin{array}{l}\text { No. of } \\
\text { oocytes }\end{array}$ & $\begin{array}{l}\text { No. of } \\
\text { MII }\end{array}$ & $\begin{array}{l}\text { Mid-luteal } \mathbf{P}_{4} \\
\quad \text { (nmol/l) }\end{array}$ \\
\hline 1 & 38 & 24.4 & 6.5 & Male factor & Long GnRHa & 3,225 & 11 & hCG 10,000 IU & Lutinus 300 mg daily & 5 & 5 & 1 & 89 \\
\hline 2 & 37 & 22.8 & 6.6 & $\begin{array}{l}\text { No male partner/ } \\
\text { endometriosis }\end{array}$ & $\begin{array}{l}\mathrm{GnRH} \\
\text { antagonist }\end{array}$ & 1,725 & 9 & Suprefact $0.5 \mathrm{mg}$ & $\begin{array}{l}\text { Lutinus } 300 \text { mg } \\
\text { daily }+1,500 \text { hCG } \\
(\mathrm{OPU})+1,000 \text { hCG } \\
(\mathrm{OPU}+5)\end{array}$ & 10 & 11 & 10 & 283 \\
\hline 3 & 39 & 30.0 & 6.4 & No male partner & Long GnRHa & 3,450 & 12 & Ovitrelle 6,500 IU & Lutinus 300 mg daily & 14 & 12 & 12 & 277 \\
\hline 4 & 34 & 22.2 & 14.7 & Unexplained & Long GnRHa & 3,600 & 12 & hCG 10,000 IU & Lutinus 300 mg daily & 9 & 8 & 8 & 213 \\
\hline 5 & 28 & 19.9 & 5.9 & Male factor & Long GnRHa & 2,925 & 11 & hCG 10,000 IU & Lutinus 300 mg daily & 9 & 6 & 3 & 97 \\
\hline 6 & 37 & 25.3 & 8.3 & Unexplained & Long GnRHa & 3,600 & 12 & Ovitrelle 6,500 IU & Lutinus 300 mg daily & 11 & 8 & 8 & 376 \\
\hline 7 & 28 & 31.8 & 3.9 & Endometriosis & $\begin{array}{l}\text { GnRH } \\
\text { antagonist }\end{array}$ & 2,025 & 9 & Suprefact $0.5 \mathrm{mg}$ & $\begin{array}{l}\text { Crinone } 180 \\
\text { daily }+1,500 \text { hCG } \\
\text { (OPU) }\end{array}$ & 17 & 11 & 11 & 36 \\
\hline 8 & 36 & 25.6 & 4.9 & Tubal factor & $\begin{array}{l}\text { GnRH } \\
\text { antagonist }\end{array}$ & 1,913 & 9 & Suprefact $0.5 \mathrm{mg}$ & $\begin{array}{l}\text { Crinone } 180 \\
\text { daily }+1,500 \text { hCG } \\
\text { (OPU) }\end{array}$ & 19 & 13 & 13 & 55 \\
\hline 9 & 40 & 34.5 & 7.2 & Unexplained & Long GnRHa & 2,250 & 9 & hCG 10,000 IU & Lutinus 300 mg daily & 7 & 6 & 6 & 54 \\
\hline 10 & 36 & 29.4 & 7.2 & Male factor & $\begin{array}{l}\text { GnRH } \\
\text { antagonist }\end{array}$ & 3,938 & 15 & Suprefact $0.5 \mathrm{mg}$ & $\begin{array}{l}\text { Lutinus } 300 \mathrm{mg} \\
\text { daily }+1,000 \mathrm{hCG} \\
(\mathrm{OPU})+500(\mathrm{OPU}+5)\end{array}$ & 20 & 14 & 8 & 161 \\
\hline
\end{tabular}

Mid-luteal $P_{4}=$ median progesterone level ( $(\mathrm{nmol} / \mathrm{l}) 7$ days after oocyte retrieval.

hCG, human chorionic gonadotropin; OPU, oocyte pick-up. 
determined individually based on patient age, $\mathrm{BMI}$, baseline $\mathrm{FSH}$, previous response to gonadotropins, and antral follicle count and adjusted by monitoring follicular size by transvaginal ultrasound during treatment. Final oocyte maturation was induced with either hCG 10,000 IU SC (Pregnyl ${ }^{\circledR}$, MSD, Denmark) or 6,500 IU SC (Ovitrelle ${ }^{\circledR}$, Merck Biopharma, Denmark) when two or more leading follicles reached a mean diameter of $17 \mathrm{~mm}$. Oocyte retrieval was carried out $36 \mathrm{~h}$ after hCG administration. IVF/ICSI procedures and embryo culture were performed according to normal clinical practice. A maximum of two embryos were transfered on day 3 or day 5 after oocyte retrieval. Luteal phase support was given as vaginal micronized $\mathrm{P}_{4}$ (Lutinus $^{\circledR} 300 \mathrm{mg}$ daily, Ferring Pharmaceutical, Denmark or Crinone ${ }^{\circledR} 180 \mathrm{mg}$ daily, Merck Biopharma, Denmark) starting 1 day after oocyte pick-up (OPU).

In four patients the GnRH antagonist protocol was used. On day 2 of the cycle ovarian stimulation commenced with either r-FSH (Gonal-F ${ }^{\circledR}$; Merck Biopharma, Denmark) or hMG (Menopur $^{\circledR}$, Ferring Pharmaceuticals, Denmark) after a vaginal ultrasound examination. Daily GnRH antagonist co-treatment (Orgalutran $^{\circledR} 0.25 \mathrm{mg} /$ day, MSD, Denmark) was added at a follicle size of $12 \mathrm{~mm}$. The FSH dose was individually adjusted according to the ovarian response. Final oocyte maturation was induced with SC Buserelin 0.5 mg (Suprefact ${ }^{\circledR}$; Sanofi, Denmark) as soon as two or more follicles of $\geq 17 \mathrm{~mm}$ were present. Oocyte retrieval was carried out $36 \mathrm{~h}$ later. A maximum of two embryos were transferred on day 3 or day 5 after OPU. Luteal phase support was given in an individualized regimen consisting of vaginal administration of $300 \mathrm{mg}$ micronized $\mathrm{P}_{4}$ daily (Lutinus ${ }^{\circledR}$, Ferring Pharmaceuticals, Denmark) in combination with a bolus of hCG $(1,000-1,500 \mathrm{IU})$ on the day of oocyte retrieval $(5,10)$. Based on the individual ovarian response to stimulation, some patients received an additional hCG bolus on OPU + 5 (500-1,000 IU)
(10). See Table 1 for details. Vaginal $\mathrm{P}_{4}$ administration continued until the day of pregnancy testing (hCG trigger) or until seventh gestational week (GnRHa trigger).

\section{Blood Sampling}

Blood sampling was conducted during the mid-luteal phase, i.e., 7 days after OPU (OPU + 7). Patients were admitted to the fertility unit early in the morning and stayed at the clinic for the subsequent $12 \mathrm{~h}$. The starting time for blood sampling was between 6 a.m. and 9 a.m. for all patients. Participants were allowed normal daily life activities during the study period.

An intravenous cannula was inserted into a vein in the antecubital fossa and blood samples $(4 \mathrm{ml})$ were drawn every $60 \mathrm{~min}$ for $12 \mathrm{~h}(n=10)$ and for two of these hours every $15 \min (n=8$ because of difficult venous access in two patients). After coagulation at room temperature, blood samples were centrifuged and serum was isolated and stored at $-80^{\circ} \mathrm{C}$ until analysis.

\section{Hormone Measurement}

Serum $\mathrm{P}_{4}(\mathrm{nmol} / \mathrm{l}), \mathrm{E}_{2}$ (pmol/l), and LH (IU/l) concentrations were measured using automated electro chemiluminescent immunoassays (Cobas ${ }^{\circledR}$ Modular analytics E170, Roche Diagnostics, Switzerland) routinely used for analysis at Department of Biochemistry, Viborg Regional Hospital, Denmark. All measurements were performed according to manufacturer's instructions using a commercially available chemiluminescent immunoassay kit intended for measurements in serum.

The detection limit of hormones was $0.2 \mathrm{nmol} / \mathrm{l}, 18.4 \mathrm{pmol} / \mathrm{l}$, and $0.1 \mathrm{IU} / 1$ for $\mathrm{P}_{4}, \mathrm{E}_{2}$, and $\mathrm{LH}$, respectively. All serum samples from each patient were measured within the same assay run. All hormone concentrations above the assay detection limit were measured in duplicate. The intra-assay coefficients of variation for $\mathrm{P}_{4}, \mathrm{E}_{2}$, and $\mathrm{LH}$ were all below $4 \%$.

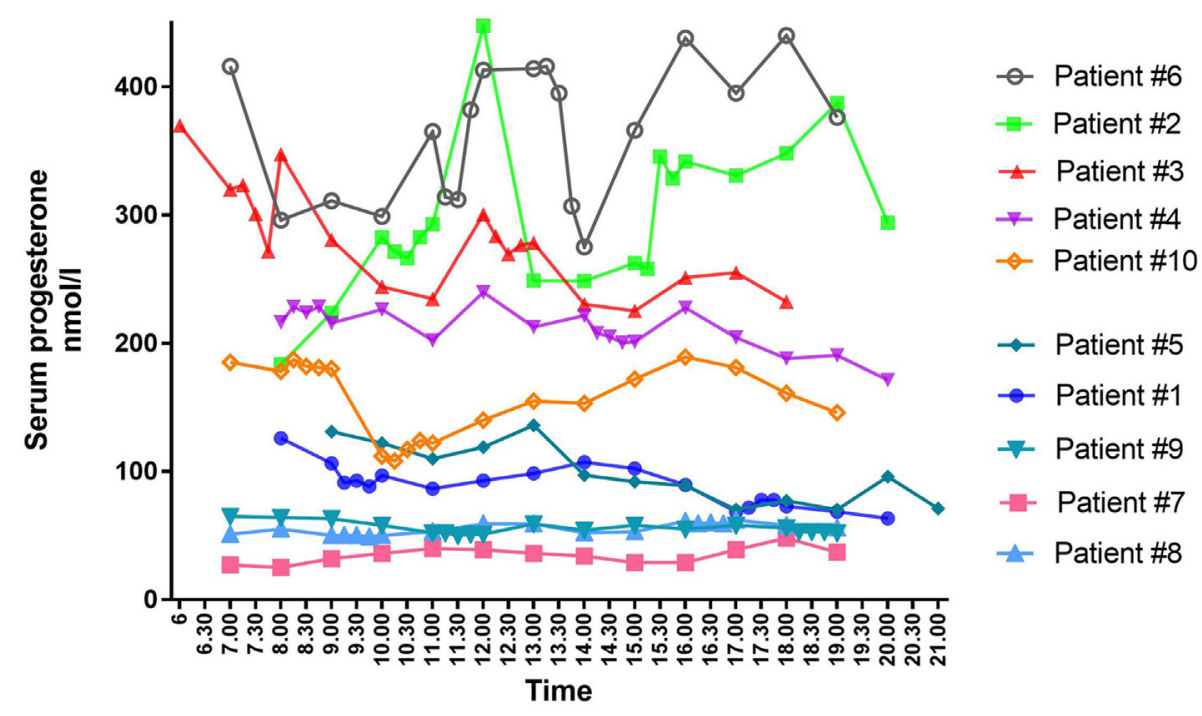

FIGURE 1 | Individual mid-luteal serum profiles of progesterone over a 12-h interval in 10 patients undergoing controlled ovarian stimulation for in vitro fertilization treatment. 


\section{Statistics}

Data are presented as mean \pm SD or median and range when appropriate. The maximum absolute variation $(\mathrm{MAV})$ in serum $\mathrm{P}_{4}$ over a 12-h period is given as the maximum $\mathrm{P}_{4}$ concentration - minimum $\mathrm{P}_{4}$ concentration during the time of sampling for each patient.

Spearman's correlation coefficient $(r)$ was calculated to correlate median steroid levels with the maximum absolute hormone variation during the day (MAV). A $p$ value $<0.05$ was considered to be statistically significant. All analyses were performed using STATA, version 13.

\section{Ethics}

The study was conducted according to the declaration of Helsinki for Medical Research and approved by the local Ethics Committee of the Central Denmark Region. ClinicalTrial.gov registration number NCT02673034.

\section{RESULTS}

\section{Patient Characteristics}

Patients had a mean age of $35.3 \pm 4.2$ years, mean BMI of $26.6 \pm 4.7 \mathrm{~kg} / \mathrm{m}^{2}$ and $1.9 \pm 2.0$ prior IVF attempts. Median level of FSH for all patients was $6.55 \mathrm{UI} / 1$ (interquartile range 5.9;7.2 IU/l). All participants were non-smokers. In four patients the cause of infertility was non-female (male factor or no male partner), in three patients the cause was female (tubal factor or endometriosis) and in three patients the cause of infertility was idiopathic (unexplained). See Table 1 for details.

\section{Overall Mid-Luteal Progesterone Values}

Three patients had median mid-luteal $\mathrm{P}_{4}$ levels below $60 \mathrm{nmol} / \mathrm{l}$. Two of these patients (\#7 and \#8) were triggered with a $\mathrm{GnRH}$ agonist and received luteal phase support with 1,500 IU hCG (OPU) and vaginal $\mathrm{P}_{4}$ (Crinone $180 \mathrm{mg}$ daily). Despite having 19 and 17 follicles $\geq 14 \mathrm{~mm}$ and 11-13 mature oocytes retrieved at the day of OPU they presented with a mid-luteal $\mathrm{P}_{4}$ of only 55 and $36 \mathrm{nmol} / \mathrm{l}$, respectively. The other patient (\#9) with $\mathrm{P}_{4}<60 \mathrm{nmol} / \mathrm{l}$ was triggered with $10,000 \mathrm{IU}$ hCG and had seven follicles $>14 \mathrm{~mm}$ at the day of aspiration.

\section{Overall Mid-Luteal LH Values}

None of the patients downregulated in a long GnRH agonist protocol $(n=6)$ had s-LH levels above the detection limit of the assay at any point during measurement (i.e., $\mathrm{LH}<0.1 \mathrm{IU} / \mathrm{l}$ ). In three of the four patients stimulated in the $\mathrm{GnRH}$ antagonist protocol a modest LH pulse activity was seen with LH amplitudes ranging from 0.2 to $2.8 \mathrm{UI} / \mathrm{l}$. In all patients, the $\mathrm{LH}$ peak was followed by an increase in serum $\mathrm{P}_{4}$ ranging from 4 to $36 \mathrm{nmol} / \mathrm{l}$.

\section{Daytime Variation in Serum Progesterone}

As seen during the natural cycle, large fluctuations in mid-luteal $\mathrm{P}_{4}$ were also present during daytime in some of the women undergoing IVF treatment (Figure 1). Fluctuations in luteal steroids were seen independent of the choice of stimulation protocol, the mode of final oocyte maturation and the type of luteal phase support.
The largest variation in $\mathrm{P}_{4}$ levels was seen in patients with median $\mathrm{P}_{4}>250 \mathrm{nmol} / \mathrm{l}$. In patient \#2 with a median $\mathrm{P}_{4}$ of $283 \mathrm{nmol} / \mathrm{l}, \mathrm{P}_{4}$ fluctuated from $293 \mathrm{nmol} / \mathrm{l}$ at $11 \mathrm{a} . \mathrm{m}$. to $448 \mathrm{nmol} / \mathrm{l}$ at 12 p.m.-i.e., an increase of $155 \mathrm{nmol} / \mathrm{l}$ within $1 \mathrm{~h}$. This fluctuation in $\mathrm{P}_{4}$ level was present even though s-LH was under the detection level throughout the day (Figure 2A). The increase in $\mathrm{P}_{4}$ was accompanied by a comparable increase in $\mathrm{E}_{2}$ (Figure $2 \mathrm{~A}$ ). Serum $\mathrm{P}_{4}$ concentrations during the 12 -h period for that specific patient ranged from $183 \mathrm{nmol} / \mathrm{l}$ early in the morning to $448 \mathrm{nmol} / \mathrm{l}$ during the day-thus, a MAV during the study period of $\Delta 265 \mathrm{nmol} / \mathrm{l}$. In patient \#6 (median $\mathrm{P}_{4} 376 \mathrm{nmol} / \mathrm{l}$ ) and \#3 (median $\mathrm{P}_{4}$ $277 \mathrm{nmol} / \mathrm{l})$ a rapid elevation of $\mathrm{P}_{4}$ levels $(\Delta 70-75 \mathrm{nmol} / \mathrm{l}$, respectively) was seen within a period of only $15 \mathrm{~min}$ without any concomitant LH activity $(\mathrm{LH}<0.1 \mathrm{IU} / \mathrm{l})$. In comparison, patient \#7 had a median $\mathrm{P}_{4}$ of only $36 \mathrm{nmol} / \mathrm{l}$ and showed only minor fluctuations throughout the day with $\mathrm{P}_{4}$ levels ranging from 25 to $48 \mathrm{nmol} / \mathrm{l}$ following a small detectable increase in $\mathrm{LH}$ secretion (see Table 2 for complete daytime $\mathrm{P}_{4}$ values).

There was a positive correlation between median $\mathrm{P}_{4}$ levels and MAV in $\mathrm{P}_{4}$ during daytime (Spearman's $r=0.9273, p=0.0001$ ).
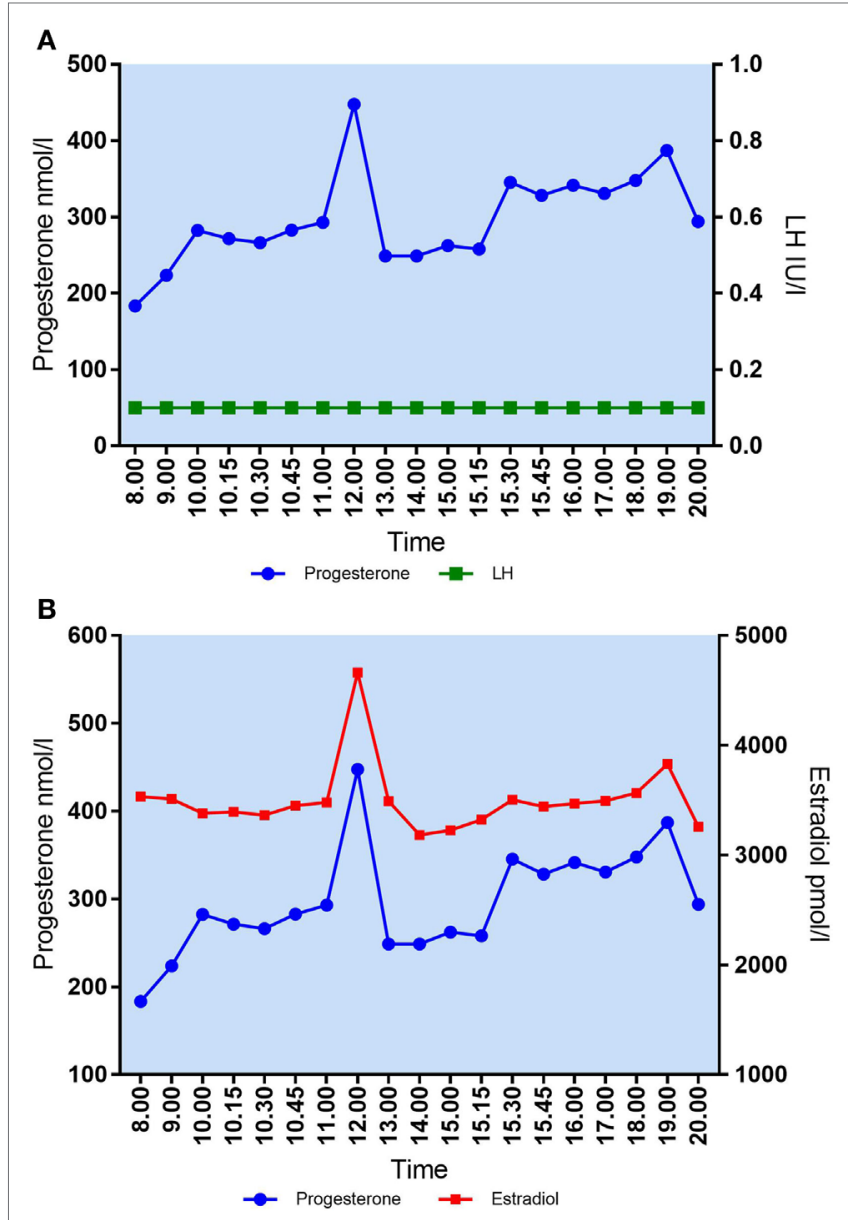

FIGURE 2 | (A) Daytime variation in mid-luteal s-progesterone and S-LH in patient \#2. Median $\mathrm{P}_{4}=283 \mathrm{nmol} / \mathrm{l}$. Maximal variation $\mathrm{P}_{4} / 12 \mathrm{~h}=265 \mathrm{nmol} / \mathrm{l}$. (B) Daytime variation in mid-luteal s-progesterone and s-estradiol in patient \#2. Median $\mathrm{E}_{2}=3,471 \mathrm{pmol} / \mathrm{l}$. Maximal variation $\mathrm{E}_{2} / 12 \mathrm{~h}=1,481 \mathrm{pmol} / \mathrm{l}$. 
TABLE 2 | Mid-luteal serum progesterone concentrations during daytime in 10 women undergoing in vitro fertilization treatment.

Patient

1

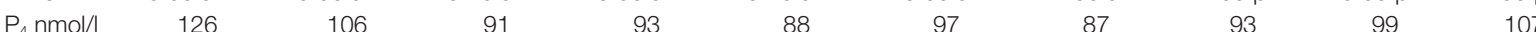

15 p.m. $\quad 16$ p.m. $\quad 17$ p.m. $\quad 17.15$ p.m. $\quad 17.30$ p.m. $\quad 17.45$ p.m. $\quad 18$ p.m. $\quad 19$ p.m. 20 p.m.

$\begin{array}{llllllllll}102 & 89 & 69 & 72 & 78 & 78 & 73 & 67 & 63 & \Delta \mathrm{P}_{4}: 63\end{array}$

2

Time $\quad 8.00$ a.m. $\quad 9.00$ a.m. $\quad 10.00$ a.m. $\quad 10.15$ a.m. $\quad 10.30$ a.m. $\quad 10.45$ a.m. $\quad 11.00$ a.m. 12.00 p.m. $\quad 13.00$ p.m. $\quad 14.00$ p.m.

$\begin{array}{lllllllll}\mathrm{P}_{4} \mathrm{nmol} / \mathrm{l} & 183 & 224 & 283 & 271 & 266 & 283 & 293 & 448\end{array}$

15.00 p.m. $\quad 15.15$ p.m. $\quad 15.30$ p.m. $\quad 15.45$ p.m. $\quad 16.00$ p.m. $\quad 17.00$ p.m. $\quad 18.00$ p.m. $\quad 19.00$ p.m. 20.00 p.m. $\quad 283$ (183-448)

$\begin{array}{lllllllll}262 & 258 & 345 & 328 & 342 & 331 & 348 & 387 & 294\end{array}$

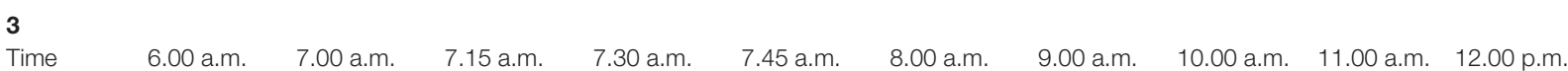

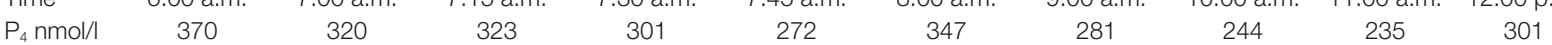

12.15 p.m. 12.30 p.m. $\quad 12.45$ p.m. $\quad 13.00$ p.m. $\quad 14.00$ p.m. $\quad 15.00$ p.m. $\quad 16.00$ p.m. $\quad 17.00$ p.m. $\quad 18.00$ p.m. $\quad 277$ (225-370)

$\begin{array}{lllllllll}283 & 269 & 277 & 278 & 230 & 225 & 251 & 255 & 232\end{array}$

\begin{tabular}{|c|c|c|c|c|c|c|c|c|c|c|c|}
\hline \multicolumn{12}{|l|}{4} \\
\hline $\begin{array}{l}\text { Time } \\
\mathrm{P}_{4} \mathrm{nmol} / \mathrm{l}\end{array}$ & $\begin{array}{c}8.00 \text { a.m. } \\
216\end{array}$ & $\begin{array}{c}8.15 \text { a.m. } \\
228\end{array}$ & $\begin{array}{c}8.30 \text { a.m. } \\
224\end{array}$ & $\begin{array}{c}8.45 \text { a.m. } \\
228\end{array}$ & $\begin{array}{c}9.00 \text { a.m. } \\
216\end{array}$ & $\begin{array}{c}10.00 \text { a.m. } \\
226\end{array}$ & $\begin{array}{c}11.00 \text { a.m. } \\
202\end{array}$ & $\begin{array}{c}12.00 \text { p.m. } \\
240\end{array}$ & $\begin{array}{c}13.00 \text { p.m. } \\
213\end{array}$ & $\begin{array}{c}14.00 \text { p.m. } \\
222\end{array}$ & \\
\hline & $\begin{array}{c}14.15 \text { p.m. } \\
208\end{array}$ & $\begin{array}{c}14.30 \text { p.m. } \\
205\end{array}$ & $\begin{array}{c}14.45 \text { p.m. } \\
200\end{array}$ & $\begin{array}{c}15.00 \text { p.m. } \\
201\end{array}$ & $\begin{array}{c}16.00 \text { p.m. } \\
228\end{array}$ & $\begin{array}{c}17.00 \text { p.m. } \\
204\end{array}$ & $\begin{array}{c}18.00 \text { p.m. } \\
188\end{array}$ & $\begin{array}{c}19.00 \text { p.m. } \\
190\end{array}$ & $\begin{array}{c}20.00 \text { p.m. } \\
171\end{array}$ & & $\begin{array}{c}213(171-240) \\
\Delta \mathrm{P}_{4}: 69\end{array}$ \\
\hline
\end{tabular}

$\begin{array}{llllll}5 & & & & \end{array}$ a.m. $\quad 10.00$ a.m. $\quad 11.00$ a.m. $\quad 12.00$ p.m. $\quad 13.00$ p.m. $\quad 14.00$ p.m. $\quad 15.00$ p.m. $\quad 16.00$ p.m. $\quad 17.00$ p.m. $\quad 18.00$ p.m.

$\begin{array}{lllllllll}\mathrm{P}_{4} \mathrm{nmol} / \mathrm{l} & 131 & 122 & 110 & 119 & 136 & 97 & 92 & 79\end{array}$ 19.00 p.m. 20.00 p.m. 21.00 p.m.

$70 \quad 96 \quad 71 \quad \Delta \mathrm{P}_{4}: 66$

\begin{tabular}{|c|c|c|c|c|c|c|c|c|c|c|c|}
\hline \multicolumn{12}{|l|}{6} \\
\hline $\begin{array}{l}\text { Time } \\
\mathrm{P}_{4} \mathrm{nmol} / \mathrm{l}\end{array}$ & $\begin{array}{c}7.00 \text { a.m. } \\
416 \\
13.15 \text { p.m. } \\
416\end{array}$ & $\begin{array}{c}8.00 \text { a.m. } \\
296 \\
13.30 \text { p.m. } \\
395\end{array}$ & $\begin{array}{c}9.00 \text { a.m. } \\
311 \\
13.45 \text { p.m. } \\
307\end{array}$ & $\begin{array}{c}10.00 \text { a.m. } \\
299 \\
14.00 \text { p.m. } \\
275\end{array}$ & $\begin{array}{c}11.00 \text { a.m. } \\
365 \\
15.00 \text { p.m. } \\
366\end{array}$ & $\begin{array}{c}11.15 \text { a.m. } \\
314 \\
16.00 \text { p.m. } \\
438\end{array}$ & $\begin{array}{c}11.30 \text { a.m. } \\
312 \\
17.00 \text { p.m. } \\
395\end{array}$ & $\begin{array}{c}11.45 \text { a.m. } \\
382 \\
18.00 \text { p.m. } \\
440\end{array}$ & $\begin{array}{c}12.00 \text { p.m. } \\
413 \\
19.00 \text { p.m. } \\
376\end{array}$ & $\begin{array}{c}13.00 \text { p.m. } \\
414\end{array}$ & $\begin{array}{c}376(275-440) \\
\Delta \mathrm{P}_{4}: 165\end{array}$ \\
\hline \multicolumn{12}{|l|}{7} \\
\hline $\begin{array}{l}\text { Time } \\
\mathrm{P}_{4} \mathrm{nmol} / \mathrm{l}\end{array}$ & $\begin{array}{c}7.00 \text { a.m. } \\
27 \\
17.00 \text { p.m. } \\
39\end{array}$ & $\begin{array}{c}8.00 \text { a.m. } \\
25 \\
18.00 \text { p.m. } \\
48\end{array}$ & $\begin{array}{c}9.00 \text { a.m. } \\
32 \\
19.00 \text { p.m. } \\
37\end{array}$ & $\begin{array}{c}10.00 \text { a.m. } \\
36\end{array}$ & $\begin{array}{c}11.00 \text { a.m. } \\
40\end{array}$ & $\begin{array}{c}12.00 \text { p.m. } \\
39\end{array}$ & $\begin{array}{c}13.00 \text { p.m. } \\
36\end{array}$ & $\begin{array}{c}14.00 \text { p.m. } \\
34\end{array}$ & $\begin{array}{c}15.00 \text { p.m. } \\
29\end{array}$ & $\begin{array}{c}16.00 \text { p.m. } \\
29\end{array}$ & $\begin{array}{c}36(25-48) \\
\Delta \mathrm{P}_{4}: 23\end{array}$ \\
\hline \multicolumn{12}{|l|}{8} \\
\hline $\begin{array}{l}\text { Time } \\
\mathrm{P}_{4} \mathrm{nmol} / \mathrm{l}\end{array}$ & $\begin{array}{c}7.00 \text { a.m. } \\
51 \\
14.00 \text { p.m. } \\
52\end{array}$ & $\begin{array}{c}8.00 \text { a.m. } \\
55 \\
15.00 \text { p.m. } \\
53\end{array}$ & $\begin{array}{c}9.00 \text { a.m. } \\
50 \\
16.00 \text { p.m. } \\
61\end{array}$ & $\begin{array}{c}9.15 \text { a.m. } \\
50 \\
16.15 \text { p.m. } \\
59\end{array}$ & $\begin{array}{c}9.30 \text { a.m. } \\
50 \\
16.30 \text { p.m. } \\
60\end{array}$ & $\begin{array}{c}9.45 \text { a.m. } \\
49 \\
16.45 \text { p.m. } \\
59\end{array}$ & $\begin{array}{c}10.00 \text { a.m. } \\
50 \\
17.00 \text { p.m. } \\
62\end{array}$ & $\begin{array}{c}11.00 \text { a.m. } \\
53 \\
18.00 \text { p.m. } \\
58\end{array}$ & $\begin{array}{c}12.00 \text { p.m. } \\
59 \\
19.00 \text { p.m. } \\
56\end{array}$ & $\begin{array}{c}13.00 \text { p.m. } \\
59\end{array}$ & $\begin{array}{c}55(49-62) \\
\Delta \mathrm{P}_{4}: 13\end{array}$ \\
\hline \multicolumn{12}{|l|}{9} \\
\hline $\begin{array}{l}\text { Time } \\
\mathrm{P}_{4} \mathrm{nmol} / \mathrm{l}\end{array}$ & $\begin{array}{c}7.00 \text { a.m. } \\
65 \\
14.00 \text { p.m. } \\
54\end{array}$ & $\begin{array}{c}8.00 \text { a.m. } \\
64 \\
15.00 \text { p.m. } \\
58\end{array}$ & $\begin{array}{c}9.00 \text { a.m. } \\
63 \\
16.00 \text { p.m. } \\
55\end{array}$ & $\begin{array}{c}10.00 \text { a.m. } \\
58 \\
17.00 \text { p.m. } \\
58\end{array}$ & $\begin{array}{c}11.00 \text { a.m. } \\
52 \\
18.00 \text { p.m. } \\
56\end{array}$ & $\begin{array}{c}11.15 \text { a.m. } \\
52 \\
18.15 \text { p.m. } \\
53\end{array}$ & $\begin{array}{c}11.30 \text { a.m. } \\
50 \\
18.30 \text { p.m. } \\
53\end{array}$ & $\begin{array}{c}11.45 \text { a.m. } \\
51 \\
18.45 \text { p.m. } \\
53\end{array}$ & $\begin{array}{c}12.00 \text { p.m. } \\
51 \\
19.00 \text { p.m. } \\
52\end{array}$ & $\begin{array}{c}13.00 \text { p.m. } \\
59\end{array}$ & $\begin{array}{c}54(51-65) \\
\Delta \mathrm{P}_{4}: 14\end{array}$ \\
\hline \multicolumn{12}{|l|}{10} \\
\hline $\begin{array}{l}\text { Time } \\
\mathrm{P}_{4} \mathrm{nmol} / \mathrm{l}\end{array}$ & $\begin{array}{c}7.00 \text { a.m. } \\
185 \\
11.00 \text { a.m. } \\
122\end{array}$ & $\begin{array}{c}8.00 \text { a.m. } \\
178 \\
12.00 \text { p.m. } \\
140\end{array}$ & $\begin{array}{c}8.15 \text { a.m. } \\
187 \\
13.00 \text { p.m. } \\
155\end{array}$ & $\begin{array}{c}8.30 \text { a.m. } \\
182 \\
14.00 \text { p.m. } \\
153\end{array}$ & $\begin{array}{c}8.45 \text { a.m. } \\
181 \\
15.00 \text { p.m. } \\
172\end{array}$ & $\begin{array}{c}9.00 \text { a.m. } \\
180 \\
16.00 \text { p.m. } \\
189\end{array}$ & $\begin{array}{c}10.00 \text { a.m. } \\
112 \\
17.00 \text { p.m. } \\
18\end{array}$ & $\begin{array}{c}10.15 \text { a.m. } \\
108 \\
18.00 \text { p.m. } \\
161\end{array}$ & $\begin{array}{c}10.30 \text { a.m. } \\
117 \\
19.00 \text { p.m. } \\
146\end{array}$ & $\begin{array}{c}10.45 \text { a.m. } \\
124\end{array}$ & $\begin{array}{c}161(108-189) \\
\Delta \mathrm{P}_{4}: 81\end{array}$ \\
\hline
\end{tabular}

$\Delta P_{4}=$ individual maximum absolute variation in $P_{4}$ during daytime $=$ maximum $P_{4}-$ minimum $P_{4}$ concentration (nmol/I).

$\mathrm{P}_{4}$ SI conversion factor: $\mathrm{nmol} / \mathrm{l}=3.18^{*} \mathrm{ng} / \mathrm{ml}$.

The magnitude of $\mathrm{P}_{4}$ pulses and thus the maximum variation is dependent on the median mid-luteal $\mathrm{P}_{4}$ concentration (Figure 3). In patients with median $\mathrm{P}_{4}>250 \mathrm{nmol} / \mathrm{l}$, very large fluctuations in serum $\mathrm{P}_{4}$ were seen during daytime with a median MAV of $165 \mathrm{nmol} / \mathrm{l}$ (range $145-265 \mathrm{nmol} / \mathrm{l}$ ). Patients with median $\mathrm{P}_{4}$ between 89 and $213 \mathrm{nmol} / \mathrm{l}$ had median MAV of $68 \mathrm{nmol} / \mathrm{l}$ (range 63-81 nmol/l), whereas patients with very low mid-luteal $\mathrm{P}_{4}$ levels (median $\mathrm{P}_{4}<60 \mathrm{nmol} / \mathrm{l}$ ) had fairly constant serum 


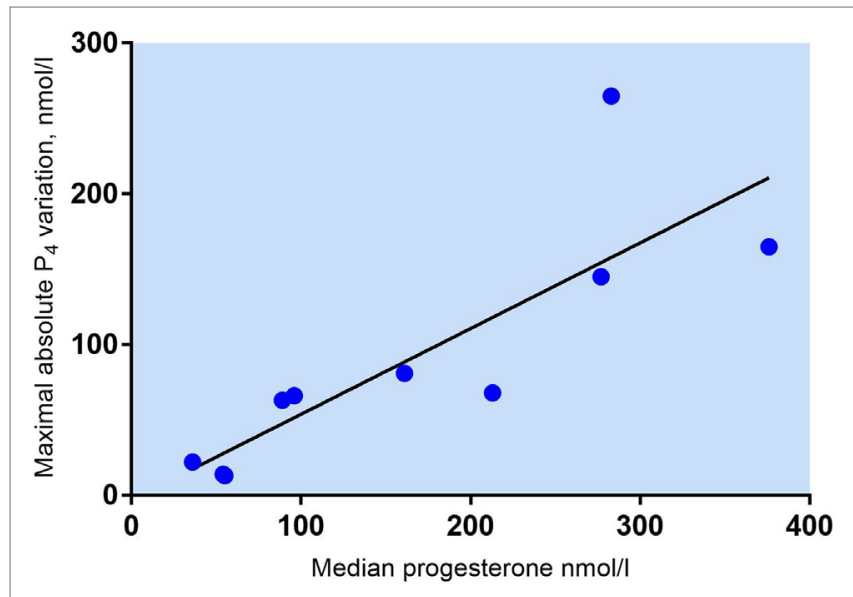

FIGURE 3 | Maximum absolute variation in s-progesterone $=\mathrm{P}_{4}$ maximum $-\mathrm{P}_{4}$ minimum $(\mathrm{nmol} / \mathrm{l})$ in 10 patients undergoing in vitro fertilization treatment. Spearman's $r=0.9273, p=0.0001$.

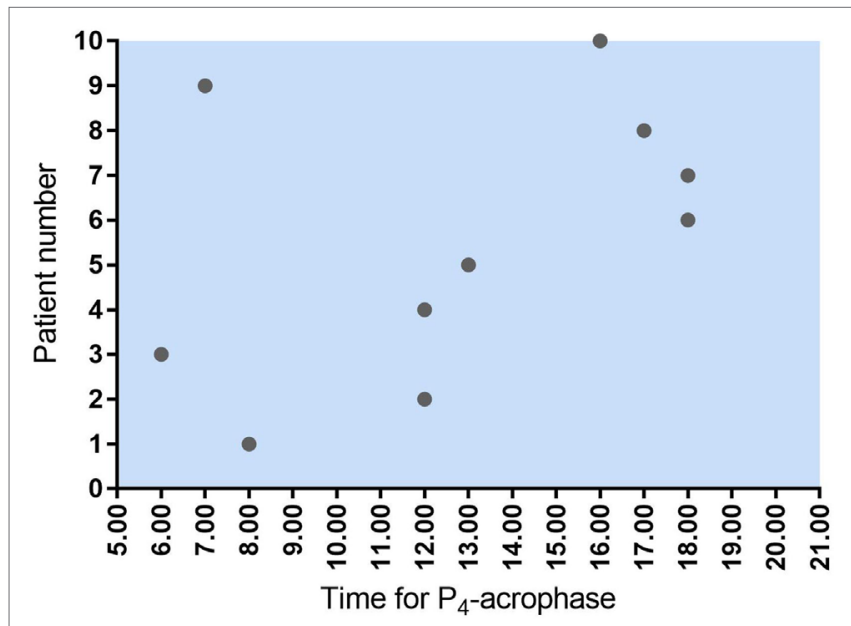

FIGURE 4 | Time for maximum $\mathrm{P}_{4}$ concentration (acrophase) in 10 women undergoing IVF treatment. As seen, five women had their $\mathrm{P}_{4}$ acrophase before noon and five after noon. The same pattern was seen for $\mathrm{P}_{4}$ nadir.

$\mathrm{P}_{4}$ levels throughout the day (median MAV $14 \mathrm{nmol} / \mathrm{l}$, range 13-23 nmol/l).

There was no common general daytime rhythm for $\mathrm{P}_{4}$ in the 10 women examined, suggesting that the luteal phase is patient specific. Some patients had their highest hormone levels in the morning-others peaked during the day or in the early evening (see Figure 1). The time of $\mathrm{P}_{4}$ acrophase (zenith) and $\mathrm{P}_{4}$ nadir was before noon in half of the patients and after noon in the other half of patients (Figure 4).

\section{Daytime Variation in Serum Estradiol}

Large fluctuations in mid-luteal serum $\mathrm{E}_{2}$ were also seen during the 12-h sampling time. In patient \#2, $\mathrm{E}_{2}$ increased from 3,480 to $4,664 \mathrm{pmol} / \mathrm{l}$ in $1 \mathrm{~h}(\Delta 1,184 \mathrm{nmol} / \mathrm{l})$ (Figure 2B). Patients had individual maximum $\mathrm{E}_{2}$ variations $\left(\mathrm{Max}_{2}-\operatorname{Min} \mathrm{E}_{2}\right.$ ) over $12 \mathrm{~h}$ ranging from $\Delta 404$ to $\Delta 1,481 \mathrm{pmol} / \mathrm{l}$. There was no correlation between median $\mathrm{E}_{2}$ levels and MAV in mid-luteal $\mathrm{E}_{2}$ (Spearman's $r=0.4424, p=0.20$ ).

As expected, $\mathrm{P}_{4}$ and $\mathrm{E}_{2}$ seem to be co-secreted from the CL showing similar patterns of fluctuations over time (Figure 5). Patients with median $\mathrm{P}_{4}<60 \mathrm{nmol} / \mathrm{l}$ had $\mathrm{E}_{2}$ ranging from 541 to $1,552 \mathrm{pmol} / \mathrm{l}$ (median $\mathrm{E}_{2} 1,457 \mathrm{pmol} / \mathrm{l}$ ) whereas patients with median $\mathrm{P}_{4}$ between 89 and $213 \mathrm{nmol} / \mathrm{l}$ had $\mathrm{E}_{2}$ levels from 659 to $4,884 \mathrm{pmol} / \mathrm{l}$ (median $\mathrm{E}_{2} 2,843 \mathrm{pmol} / \mathrm{l}$ ). In patients with median $\mathrm{P}_{4}>250 \mathrm{nmol} / \mathrm{l}, \mathrm{E}_{2}$ ranged from 3,471 to 3,919 $\mathrm{pmol} / \mathrm{l}$ (median $\left.\mathrm{E}_{2} 3,874 \mathrm{pmol} / \mathrm{l}\right)$. There was a significant correlation between median $\mathrm{P}_{4}$ levels and median $\mathrm{E}_{2}$ levels during mid-luteal phase of the stimulated cycle (Spearman's $r=0.8424, p=0.002$ ).

\section{DISCUSSION}

To the best of our knowledge, this is the first study to explore a possible daytime variation in $\mathrm{P}_{4}$ secretion during the mid-luteal phase in a group of women undergoing IVF treatment.

We found that the magnitude of mid-luteal $\mathrm{P}_{4}$ fluctuations following IVF treatment was dependent on the median $\mathrm{P}_{4}$ level. The largest $\mathrm{P}_{4}$ variations were seen in patients with median $\mathrm{P}_{4}$ exceeding $250 \mathrm{nmol} / \mathrm{l}$ (median MAV $165 \mathrm{nmol} / \mathrm{l}$ ), whereas patients in the low $\mathrm{P}_{4}$ group (median $\mathrm{P}_{4}<60 \mathrm{nmol} / \mathrm{l}$ ) had relatively constant $\mathrm{P}_{4}$ levels throughout the day (median MAV $14 \mathrm{nmol} / \mathrm{l}$ ). Patients showed a highly individual hormone secretion pattern without any obvious common daytime rhythm in $\mathrm{P}_{4}$ secretion. Serum $\mathrm{E}_{2}$ showed similar fluctuations in the mid-luteal phase with patients having individual $\mathrm{E}_{2}$ variations ranging from $\Delta 404$ to $\Delta 1,481 \mathrm{pmol} / \mathrm{l}$ during the 12 -h study time.

Earlier studies described the highly variable pattern of $\mathrm{P}_{4}$ secretion during the mid-luteal phase of naturally cycling women $(15,19,20)$. These studies reported the presence of two distinguishable types of luteal $\mathrm{P}_{4}$ pulses-some preceded by a $\mathrm{LH}$ pulse and others non-concomitant to $\mathrm{LH}$ seen during time of pituitary quiescence. The latter seems to be the result of an autonomous $\mathrm{P}_{4}$ secretion from the $\mathrm{CL}$, triggered and maintained by intraovarian concentrations of $E_{2}$, oxytocin, and $\operatorname{PGF}_{2 \alpha}(21,22)$. The CL consists of two types of steroidogenic cells, i.e., the small luteal cells (SLCs) derived from follicular theca cells and the large luteal cells (LLCs) originating from follicular granulosa cells. Both the small and the large cells have extensive capacity to produce $\mathrm{P}_{4}$. Moreover, both cells have unique steroidogenic functions and the "two-cell" mechanism of $\mathrm{E}_{2}$ biosynthesis appear to operate in the human CL analogous to the preovulatory follicle (23). Thus, the LLCs contain P450-aromatase essential for $\mathrm{E}_{2}$ synthesis whereas SLCs express $\mathrm{P} 450 \mathrm{c} 17$ for androgen production $(24,25)$. Both types of luteal cells express $\mathrm{E}_{2}$ receptors (26) and $\mathrm{E}_{2}$ stimulation is a powerful trigger of $\mathrm{P}_{4}$ release from either cell type (27).

Isolation of large and SLCs from human corpora lutea has shown that once induced by the LH peak, the LLCs exhibit the greatest basal $\mathrm{P}_{4}$ production (28) and that this production is not increased by further LH stimulation (29). The LLCs produce $\mathrm{P}_{4}$ at a constant rate and are the dominant source of $\mathrm{P}_{4}$ during the 


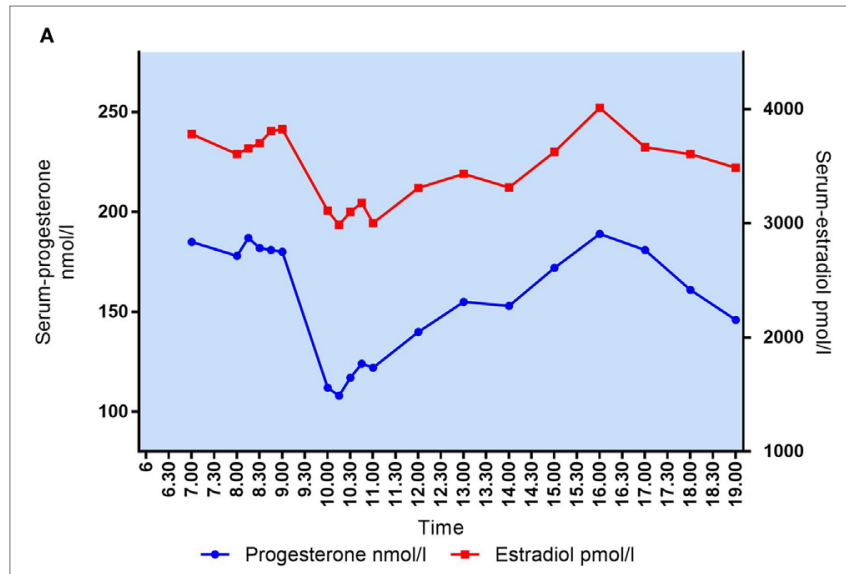

B

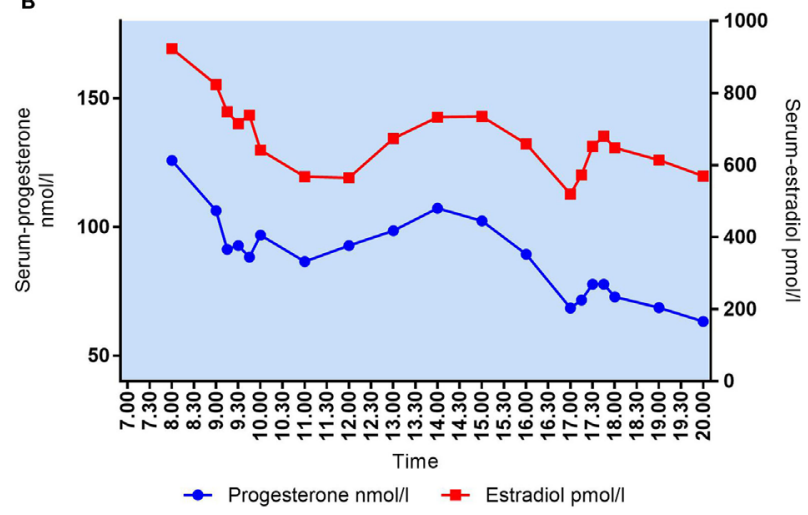

FIGURE 5 | (A) Daytime variation in mid-luteal s-progesterone and s-estradiol in patient \#10. Median $\mathrm{P}_{4}=161 \mathrm{nmol} / \mathrm{l}$, median

$\mathrm{E}_{2}=3,606 \mathrm{pmol} / \mathrm{l}$. (B) Daytime variation in mid-luteal s-progesterone and $\mathrm{s}$-estradiol in patient \#1. Median $\mathrm{P}_{4}=89 \mathrm{nmol} / \mathrm{l}$, median $\mathrm{E}_{2}=659 \mathrm{pmol} / \mathrm{l}$.

early luteal phase (30). During this period, the $\mathrm{P}_{4}$ levels exhibit a non-pulsatile pattern both in the natural (15) and stimulated cycle $(\mathrm{OPU}+2)(31)$. The responsivity of the SLCs to LH/hCG develops during the early mid-luteal phase where cells respond with a pronounced increase in $\mathrm{P}_{4}$ secretion in response to $\mathrm{LH}$ pulses. The luteal $\mathrm{P}_{4}$ contribution from the SLCs increase during the mid-and late luteal phase during which $\mathrm{P}_{4}$ secretion becomes highly pulsatile (32).

Thus, the endogenous mid-luteal $\mathrm{P}_{4}$ level consist of three parts-the basal $\mathrm{P}_{4}$ production from the LLCs, the $\mathrm{P}_{4}$ pulses from SLCs triggered by pituitary LH, and the autonomous $\mathrm{P}_{4}$ fluctuations independent of luteotrophic stimuli.

Previously, Wuttke et al. proposed a model to explain the LH-independent fluctuations in mid-luteal $\mathrm{P}_{4}$ levels based on autocrine and paracrine mechanisms in the luteal tissue (21). Upon stimulation with LH during the mid-luteal phase, the SLCs start secretion of $\mathrm{P}_{4}$ as well as androstenedione - the latter is subsequently converted to $\mathrm{E}_{2}$ in LLCs by $\mathrm{P} 450$-aromatase. The increased $\mathrm{E}_{2}$ concentration acts in an autocrine way in LLCs to increase the release of both $\mathrm{P}_{4}$ and oxytocin. Oxytocin stimulates fibroblasts to release $\mathrm{PGF}_{2 \alpha}$, which in turn stimulates further oxytocin as well as $\mathrm{E}_{2}$ secretion from the luteal cells. The isolated effect of oxytocin and $\mathrm{PGF}_{2 \alpha}$ upon the luteal cell lines is a decreased $\mathrm{P}_{4}$ secretion, but this effect is overridden by the concomitantly triggered increase in $\mathrm{E}_{2}$ which will elicit a pronounced $\mathrm{P}_{4}$ release. In this way, the LH pulse will stimulate an intra-luteal circuit involving auto-and paracrine effects of $\mathrm{E}_{2}$, oxytocin, $\mathrm{PGF}_{2 \alpha}$-and possible a variety of other regulatory peptides, i.e., Substance $\mathrm{P}$-and the net effect is the generation of $\mathrm{a}_{4}$ pulse. This circuit functions for hours without further gonadotropic support, thus generating several $\mathrm{P}_{4}$ pulses with gradually decreasing amplitude until the next $\mathrm{LH}$ pulse sets off the intra-luteal $\mathrm{E}_{2} / \mathrm{P}_{4}$ loop again. In contrast, in women with hypothalamic deficiency with suppressed LH levels and no LH pulses, mid-luteal $\mathrm{P}_{4}$ shows a non-pulsatile pattern, underlining the need for an initial high LH/hCG load to trigger the $\mathrm{P}_{4}$ circuit (21). The oxytocin induced $\mathrm{P}_{4}$ release can be prevented by treatment of the CL with tamoxifen-an estrogen receptor blocking agent-underlining the $\mathrm{E}_{2}$ regulation of the autonomous $\mathrm{P}_{4}$ pulses (27). This independent intra-luteal $\mathrm{P}_{4}$ pulse generator might serve as an additional biological safety mechanism preventing declining $\mathrm{P}_{4}$ levels in between $\mathrm{LH}$ pulses and might explain the function of the substantial $\mathrm{E}_{2}$ production during the luteal phase in humans.

In the stimulated IVF cycle, LH pulses are absent during the mid-luteal phase and serum LH levels are distinctly suppressed (33). The hCG bolus administered for ovulation induction or as luteal phase support exerts a tonic and constant stimulation on the luteal tissue due to the prolonged half-life of hCG and, therefore, cannot account for the rapid $\mathrm{P}_{4}$ fluctuations seen during the mid-luteal phase in this study. The standard vaginal $\mathrm{P}_{4}$ supplementation reaches steady state during the early luteal phase and contributes with remarkably constant serum $\mathrm{P}_{4}$ levels though out the day despite multiple daily vaginal doses (34). The very large fluctuations in serum $\mathrm{P}_{4}$ seen in the present study are, therefore, likely to be the result of the autonomous intraovarian $\mathrm{P}_{4}$ circuit. This is further emphasized by the fact that $\mathrm{P}_{4}$ peaks are accompanied by concomitant $\mathrm{E}_{2}$ rises and exogenous $\mathrm{E}_{2}$ was not provided as part of the luteal phase support.

We were not able to detect a common general pattern of $\mathrm{P}_{4}$ secretion during daytime in the 10 patients examined. The peak and nadir $\mathrm{P}_{4}$ levels occurred at different times in different patients, and the course of hormone levels during the day showed highly individual rhythms. This is in agreement with studies performed during the mid-luteal phase of the natural cycle $(3,19)$. In a study of seven women studied over $24 \mathrm{~h}$ in the mid-luteal phase of the natural cycle, the $\mathrm{P}_{4}$ acrophase varied from 10.31 a.m. to 11.33 p.m. (16). Based on the lack of a diurnal reproducible pattern for mid-luteal $\mathrm{P}_{4}$ in the IVF cycle the accuracy of the $\mathrm{P}_{4}$ measurement is not improved by a fixed timing of blood sampling and, thus, the $\mathrm{P}_{4}$ measurement could be performed at any time during clinic opening hours.

During the natural cycle both late follicular $\mathrm{E}_{2}$ levels, follicular diameter at the time of ovulation as well as area under the $\mathrm{LH}$ surge curve correlate poorly to the subsequent luteal phase $\mathrm{P}_{4}$ level (3). Thus, predicting patients with insufficient luteal $\mathrm{P}_{4}$ levels is troublesome based on the follicular development as abnormal luteal phases can be seen in cycles characterized by normal folliculogenesis (35). In the present study, the two patients with the lowest $\mathrm{P}_{4}$ levels (36 and $55 \mathrm{nmol} / \mathrm{l}$ ) had 17 and 19 follicles, respectively, on the day of OPU, showing that a large number of CLs do not warrant 
a high $\mathrm{P}_{4}$ output in the luteal phase. For this reason monitoring of luteal phase $\mathrm{P}_{4}$ could be of value to detect patients with low $\mathrm{P}_{4}$ levels, who might benefit from additional exogenous $\mathrm{P}_{4}$ therapy. However, the prerequisite for easy luteal phase monitoring is that the validity of a single measured $\mathrm{P}_{4}$ value is reliable and gives a reasonable estimate of the CL capacity of the patient.

We acknowledge that the small sample size of this study may limit the validity of general interpretations. However, we consider this explorative preliminary study to be pioneering as part of basic research and, importantly, it is the first to explore the mid-luteal $\mathrm{P}_{4}$ fluctuations in different types of IVF cycles. The autonomous $\mathrm{LH}$-independent $\mathrm{P}_{4}$ bursts from the ovaries during the mid-luteal phase were seen in both GnRH analog types (GnRH antagonist and long GnRHa protocol) as well as after different types of triggering of final oocyte maturation (hCG or GnRH agonist). Thus, it seems that these autonomous episodic luteal $\mathrm{P}_{4}$ peaks are generated independently of the choice of treatment regimen and may, therefore, also apply to other IVF stimulation protocols.

\section{CONCLUSION}

Based on the 10 women examined in this study, we state that the accuracy of a single mid-luteal serum progesterone measurement as an approximation of mean $\mathrm{P}_{4}$ levels throughout the day depends on the $\mathrm{P}_{4}$ concentration and that women with low $\mathrm{P}_{4}$ levels $\left(\mathrm{P}_{4}<60 \mathrm{nmol} / \mathrm{l}\right)$ exhibit clinically stable $\mathrm{P}_{4}$ levels during daytime. Thus, a single $\mathrm{P}_{4}$ measurement in the low progesterone patient reflects quite accurately the CL function and a measured low $\mathrm{P}_{4}$ value can, therefore, be regarded as a "true low value." Future studies should clarify, whether additional exogenous $\mathrm{P}_{4}$ support administered to the low luteal $\mathrm{P}_{4}$ patient group can improve the reproductive outcome.

\section{REFERENCES}

1. Wiltbank MC, Salih SM, Atli MO, Luo W, Bormann CL, Ottobre JS, et al. Comparison of endocrine and cellular mechanisms regulating the corpus luteum of primates and ruminants. Anim Reprod (2012) 9(3):242-59.

2. Rossmanith WG, Laughlin GA, Mortola JF, Yen SS. Secretory dynamics of oestradiol (E2) and progesterone (P4) during periods of relative pituitary LH quiescence in the midluteal phase of the menstrual cycle. Clin Endocrinol (Oxf) (1990) 32(1):13-23. doi:10.1111/j.1365-2265.1990.tb03745.x

3. Soules MR, Clifton DK, Steiner RA, Cohen NL, Bremner WJ. The corpus luteum: determinants of progesterone secretion in the normal menstrual cycle. Obstet Gynecol (1988) 71(5):659-66.

4. Humaidan P, Bungum L, Bungum M, Hald F, Agerholm I, Blaabjerg J, et al. Reproductive outcomes using a GnRH antagonist (Cetrorelix) for luteolysis and follicular synchronization in poor responder IVF/ICSI patients treated with a flexible GnRH antagonist protocol. Reprod Biomed Online (2005) 11(6):679-84. doi:10.1016/S1472-6483(10)61685-9

5. Humaidan P, Ejdrup Bredkjaer H, Westergaard LG, Yding Andersen C. 1,500 IU human chorionic gonadotropin administered at oocyte retrieval rescues the luteal phase when gonadotropin-releasing hormone agonist is used for ovulation induction: a prospective, randomized, controlled study. Fertil Steril (2010) 93(3):847-54. doi:10.1016/j.fertnstert.2008.12.042

6. Yding Andersen C, Vilbour Andersen K. Improving the luteal phase after ovarian stimulation: reviewing new options. Reprod Biomed Online (2014) 28(5):552-9. doi:10.1016/j.rbmo.2014.01.012

\section{DATA AVAILABILITY}

The raw data supporting the conclusion of this manuscript will be made available by the authors, without undue reservation, to any qualified researcher.

\section{ETHICS STATEMENT}

The study was conducted according to the declaration of Helsinki for Medical Research and approved by the local Ethics Committee of the Central Denmark Region. All patients provided written informed consent to participate in the study.

\section{AUTHOR CONTRIBUTIONS}

LT designed and conducted the study. LT drafted the manuscript and $\mathrm{UK}, \mathrm{CA}$, and $\mathrm{PH}$ all contributed to the interpretation of data and critically reviewed the manuscript. All coauthors accepted the final draft.

\section{ACKNOWLEDGMENTS}

The authors would like to thank the participating patients at the Fertility Clinic in Skive, Denmark who kindly used their time to make this study possible.

\section{FUNDING}

A grant from "Health Research Foundation of Central Denmark Region" and "The Research Foundation of the Hospital of Central Jutland" supported the conduction of this study. The providers of funding were neither involved in the conduction of the study nor in the writing of the scientific report.

7. Blake EJ, Norris PM, Dorfman SF, Longstreth J, Yankov VI. Single and multidose pharmacokinetic study of a vaginal micronized progesterone insert (Endometrin) compared with vaginal gel in healthy reproductive-aged female subjects. FertilSteril (2010) 94(4):1296-301. doi:10.1016/j.fertnstert.2009.06.014

8. Kisicki JC. Pharmacokinetic Study of Three Dosage Strengths of COL-1620 with Natural Progesterone. Columbia Research Laboratories. Data on file. Crinone Product Monograph (2008). Avaliable from: https://dailymed.nlm.nih.gov/ dailymed/drugInfo.cfm?id=13472

9. Colburn WA. Pharmacokinetic Study of $90 \mathrm{mg}$ Strength of COL-1620 with Natural Progesterone, B.I.D. Columbia Research Laboratories. Data on file. Crinone Product Monograph (2008). Avaliable from: https://dailymed.nlm. nih.gov/ dailymed/drugInfo.cfm?id=13472

10. Humaidan P, Polyzos NP, Alsbjerg B, Erb K, Mikkelsen AL, Elbaek HO, et al. GnRHa trigger and individualized luteal phase hCG support according to ovarian response to stimulation: two prospective randomized controlled multi-centre studies in IVF patients. Hum Reprod (2013) 28(9):2511-21. doi:10.1093/humrep/det249

11. Niemann H, Sacher B, Elsaesser F. Pregnancy rates relative to recipient plasma progesterone levels on the day of nonsurgical transfer of frozen/thawed bovine embryos. Theriogenology (1985) 23(4):631-9. doi:10.1016/0093691X(85)90197-9

12. Nogueira MF, Melo DS, Carvalho LM, Fuck EJ, Trinca LA, Barros CM. Do high progesterone concentrations decrease pregnancy rates in embryo recipients synchronized with PGF2alpha and eCG? Theriogenology (2004) 61(7-8):1283-90. doi:10.1016/j.theriogenology.2003.07.012 
13. Yovich JL, Conceicao JL, Stanger JD, Hinchliffe PM, Keane KN. Mid-luteal serum progesterone concentrations govern implantation rates for cryopreserved embryo transfers conducted under hormone replacement. Reprod Biomed Online (2015) 31(2):180-91. doi:10.1016/j.rbmo.2015.05.005

14. Labarta E, Mariani G, Holtmann N, Celada P, Remohi J, Bosch E. Low serum progesterone on the day of embryo transfer is associated with a diminished ongoing pregnancy rate in oocyte donation cycles after artificial endometrial preparation: a prospective study. Hum Reprod (2017) 32(12):2437-42. doi:10.1093/humrep/dex316

15. Filicori M, Butler JP, Crowley WF Jr. Neuroendocrine regulation of the corpus luteum in the human. Evidence for pulsatile progesterone secretion. J Clin Invest (1984) 73(6):1638-47. doi:10.1172/JCI111370

16. Veldhuis JD, Christiansen E, Evans WS, Kolp LA, Rogol AD, Johnson ML. Physiological profiles of episodic progesterone release during the midluteal phase of the human menstrual cycle: analysis of circadian and ultradian rhythms, discrete pulse properties, and correlations with simultaneous luteinizing hormone release. J Clin Endocrinol Metab (1988) 66(2):414-21. doi:10.1210/jcem-66-2-414

17. Reame N, Sauder SE, Kelch RP, Marshall JC. Pulsatile gonadotropin secretion during the human menstrual cycle: evidence for altered frequency of gonadotropin-releasing hormone secretion. J Clin Endocrinol Metab (1984) 59(2):328-37. doi:10.1210/jcem-59-2-328

18. Tavaniotou A, Albano C, Smitz J, Devroey P. Comparison of LH concentrations in the early and mid-luteal phase in IVF cycles after treatment with HMG alone or in association with the GnRH antagonist Cetrorelix. Hum Reprod (2001) 16(4):663-7. doi:10.1093/humrep/16.4.663

19. Fujimoto VY, Clifton DK, Cohen NL, Soules MR. Variability of serum prolactin and progesterone levels in normal women: the relevance of single hormone measurements in the clinical setting. Obstet Gynecol (1990) 76(1):71-8.

20. Rossmanith WG, Laughlin GA, Mortola JF, Johnson ML, Veldhuis JD, Yen SS. Pulsatile cosecretion of estradiol and progesterone by the midluteal phase corpus luteum: temporal link to luteinizing hormone pulses. J Clin Endocrinol Metab (1990) 70(4):990-5. doi:10.1210/jcem-70-4-990

21. Wuttke W, Theiling K, Hinney B, Pitzel L. Regulation of steroid production and its function within the corpus luteum. Steroids (1998) 63(5-6):299-305. doi:10.1016/S0039-128X(98)00037-3

22. Bah MM, Acosta TJ, Pilawski W, Deptula K, Okuda K, Skarzynski DJ. Role of intraluteal prostaglandin $\mathrm{F}$ (2alpha), progesterone and oxytocin in basal and pulsatile progesterone release from developing bovine corpus luteum. Prostaglandins Other Lipid Mediat (2006) 79(3-4):218-29. doi:10.1016/j. prostaglandins.2006.01.002

23. Fisch B, Margara RA, Winston RM, Hillier SG. Cellular basis of luteal steroidogenesis in the human ovary. JEndocrinol (1989) 122(1):303-11. doi:10.1677/joe. 0.1220303

24. Maybin JA, Duncan WC. The human corpus luteum: which cells have progesterone receptors? Reproduction (2004) 128(4):423-31. doi:10.1530/ rep. 1.00051

25. Devoto L, Fuentes A, Kohen P, Cespedes P, Palomino A, Pommer R, et al. The human corpus luteum: life cycle and function in natural cycles. Fertil Steril (2009) 92(3):1067-79. doi:10.1016/j.fertnstert.2008.07.1745
26. van den Driesche S, Smith VM, Myers M, Duncan WC. Expression and regulation of oestrogen receptors in the human corpus luteum. Reproduction (2008) 135(4):509-17. doi:10.1530/REP-07-0427

27. Maas S, Jarry H, Teichmann A, Rath W, Kuhn W, Wuttke W. Paracrine actions of oxytocin, prostaglandin F2 alpha, and estradiol within the human corpus luteum. J Clin Endocrinol Metab (1992) 74(2):306-12. doi:10.1210/jc.74.2.306

28. Friden BE, Hagstrom H, Lindblom B, Sjoblom P, Wallin A, Brannstrom M, et al. Cell characteristics and function of two enriched fraction of human luteal cells prolonged culture. Mol Hum Reprod (1999) 5(8):714-9. doi:10.1093/ molehr/5.8.714

29. Ohara A, Mori T, Taii S, Ban C, Narimoto K. Functional differentiation in steroidogenesis of two types of luteal cells isolated from mature human corpora lutea of menstrual cycle. J Clin Endocrinol Metab (1987) 65(6):1192-200. doi:10.1210/jcem-65-6-1192

30. Jones GS. Corpus luteum: composition and function. Fertil Steril (1990) 54(1):21-6. doi:10.1016/S0015-0282(16)53630-9

31. Tannus S, Burke Y, McCartney CR, Kol S. GnRH-agonist triggering for final oocyte maturation in GnRH-antagonist IVF cycles induces decreased LH pulse rate and amplitude in early luteal phase: a possible luteolysis mechanism. Gynecol Endocrinol (2017) 5:1-5. doi:10.1080/09513590.2017. 1318275

32. Jones GS. Luteal phase defect: a review of pathophysiology. Curr Opin Obstet Gynecol (1991) 3(5):641-8. doi:10.1097/00001703-199110000-00003

33. Wolfram J, Siegberg R, Apter D, Alfthan H, Stenman UH, Laatikainen T. Pulsatility of serum-luteinizing hormone during hyperstimulation with clomiphene citrate and human menopausal gonadotropin for in vitro fertilization. Fertil Steril (1989) 52(5):817-20. doi:10.1016/S0015-0282(16)53045-3

34. Devroey P, Palermo G, Bourgain C, Van Waesberghe L, Smitz J, Van Steirteghem AC. Progesterone administration in patients with absent ovaries. Int J Fertil (1989) 34(3):188-93.

35. Grunfeld L, Sandler B, Fox J, Boyd C, Kaplan P, Navot D. Luteal phase deficiency after completely normal follicular and periovulatory phases. Fertil Steril (1989) 52(6):919-23. doi:10.1016/S0015-0282(16)53152-5

Conflict of Interest Statement: LT received an unrestricted research grant from Ferring Pharmaceuticals outside of this work. PH received unrestricted research grants from MSD, Merck, and Ferring Pharmaceuticals as well as honoraria for lectures from MSD, Merck, and Finox outside of this work. UK received honoraria for lectures from MSD and Ferring Pharmaceuticals outside of this work. CA received unrestricted research grants from MSD, IBSA, and Ferring Pharmaceuticals as well as honoraria for lectures from MSD and IBSA outside of this work.

Copyright ( 2018 Thomsen, Kesmodel, Andersen and Humaidan. This is an openaccess article distributed under the terms of the Creative Commons Attribution License (CC BY). The use, distribution or reproduction in other forums is permitted, provided the original author(s) and the copyright owner are credited and that the original publication in this journal is cited, in accordance with accepted academic practice. No use, distribution or reproduction is permitted which does not comply with these terms. 